\title{
Routine On-farm Soil Tillage Helps Control Asparagus Fly (Plioreocepta Poeciloptera)
}

\author{
Alexandra Wichura' ${ }^{1}$ - Quentin Schorpp ${ }^{2}$ (D) $\cdot$ Vera Kühlmannn ${ }^{1,3}$. Martin Hommes²
}

Received: 5 September 2021 / Accepted: 23 November 2021 / Published online: 9 December 2021

(c) The Author(s) 2021

\begin{abstract}
Asparagus fly (Plioreocepta poeciloptera (Schrank, 1776)) is a serious pest in German asparagus (Asparagus officinalis L.) production. To evaluate the effects of different routine on-farm soil tillage measures on the number of flies emerging the following spring, asparagus fields in Lower Saxony, Germany, were investigated. Soil samples were taken before and after tillage in autumn 2017 and autumn 2018. Investigations were also conducted in both years on the effect that the soil depth at which asparagus fly pupae were buried had on the emergence of adult flies.

This study revealed that the number of emerging flies was not reduced by mulching, but was significantly reduced by subsequent tillage and/or tillage and dam formation. The emergence rate of adult flies was significantly reduced the deeper the pupae had been buried the previous autumn. The effects also depended on the year. The highest mean emergence rate observed was $68 \%$ and $45 \%$ for pupae buried at a depth of $10 \mathrm{~cm}$ and $20 \mathrm{~cm}$, respectively. In conclusion, the key mechanism causing a decrease in asparagus fly population the following spring through routine on-farm tillage could be the burial of pupae when forming dams. Routine on-farm soil tillage can be regarded as a physical measure for controlling asparagus fly and is therefore an essential tool in the integrated pest management of asparagus production.
\end{abstract}

Keywords Rotary tiller $\cdot$ Mulcher $\cdot$ Pupae $\cdot$ Platyparea poeciloptera $\cdot$ Plioreocepta poeciloptera $\cdot$ Integrated pest management $\cdot$ IPM

Alexandra Wichura

alexandra.wichura@1wk-niedersachsen.de

1 Chamber of Agriculture Lower Saxony, Plant Protection Service, Wunstorfer Landstr. 9, 30453 Hannover, Germany
2 Julius Kühn-Institute, Federal Research Centre for Cultivated Plants, Institute for Plant Protection in Horticulture and Forests, Messeweg 11/12, 38104 Braunschweig, Germany

3 Netzwerk Ackerbau Niedersachsen e. V., Johannsenstr. 2-3, 30159 Hannover, Germany 


\section{Die routinemäßige Bodenbearbeitung von Praxisbetrieben trägt zur Kontrolle der Spargelfliege (Plioreocepta poeciloptera) bei}

\section{Zusammenfassung}

Die Spargelfliege (Plioreocepta poeciloptera (Schrank, 1776)) ist ein ernsthafter Schädling in der deutschen Produktion von Spargel (Asparagus officinalis L.). In dieser Studie wurden die Effekte verschiedener routinemäßig durchgeführter Bodenbearbeitungsmaßnahmen auf die Anzahl der im nächsten Frühjahr erscheinenden Fliegen untersucht. Hierzu wurden im Herbst 2017 und 2018 von Spargelfeldern in Niedersachsen, Deutschland, vor und nach der Bearbeitung Bodenproben entnommen. Zusätzlich wurden in denselben Jahren Versuche zum Einfluss der Ablagetiefe der Puppen im Boden auf das Erscheinen der adulten Fliegen durchgeführt.

Es wurde gezeigt, dass die Anzahl der erscheinenden Fliegen durch Mulchen nicht reduziert wurde. Allerdings hatten die nachfolgenden Bearbeitungsschritte wie Fräsen bzw. Fräsen und Dammformen einen signifikanten Einfluss. Zusätzlich wurde die Anzahl der Fliegen signifikant reduziert, je tiefer die Puppen im vorigen Herbst im Boden vergraben worden waren. Abhängig vom Jahr erschienen bei $10 \mathrm{~cm}$ tief abgelegten Puppen maximal $68 \%$ der adulten Fliegen, bei $20 \mathrm{~cm}$ Tiefe maximal $45 \%$.

Als essenzieller Mechanismus, der bei der Durchführung der routinemäßigen Bodenbearbeitungsmaßnahmen für die Reduktion der Spargelfliegen im nächsten Jahr verantwortlich ist, könnte das Vergraben der Puppen durch das Aufsetzen der Dämme angesehen werden. Die praxisgemäße Bodenbearbeitung kann daher bereits als physikalische Maßnahme bei der Bekämpfung der Spargelfliege angesehen werden. Sie stellt somit ein entscheidendes Werkzeug bei der Umsetzung des integrierten Pflanzenschutzes in der Spargelproduktion von dar.

Schlüsselwörter Fräse $\cdot$ Mulcher $\cdot$ Puppen $\cdot$ Platyparea poeciloptera $\cdot$ Plioreocepta poeciloptera $\cdot$ Integrierter Pflanzenschutz · IPS

\section{Introduction}

The asparagus fly (Plioreocepta poeciloptera (Schrank, 1776)) is one of the main insect pests in German asparagus production (Dingler 1934a, b; Crüger et al. 2002). Its presence in Germany was reported in the early 20th century (Krüger 1905) and elsewhere in Europe, including in France (Giard 1903), Hungary, the former Czechoslovakia, Russia and Italy (Dingler 1934a), Great Britain (Niblett 1956), Switzerland (Fischer et al. 1989) and the Netherlands (van Rozen and Ester 2006), and even outside Europe in the USA (Drake and Harris 1932).

The biology of $P$. poeciloptera was first described by Dingler $(1934 a, b)$ and has been supplemented by more recent work by Otto (2002). The asparagus fly is strictly univoltine, with asparagus being the only host plant. Its flight can be observed from the beginning of April to the middle of July. Its larvae can cause severe damage, especially in young asparagus plantations.

Farmers routinely cut and shred the asparagus fern with mulching devices in autumn. Depending on the growing region and individual preferences, small winter dams or filmcovered dams are formed either immediately after mulching or within a few weeks. A variety of different devices are available, but for soil tillage some kind of rotary tiller is mostly used. Up to now, little has been known about the contribution made by routine mechanical processing to the control of asparagus fly overall and the benefits of this as part of integrated pest management.

However, on-farm trials with asparagus are difficult to conduct as film and tunnel management, harvesting and mechanical and chemical treatments may either disturb the trial or the trial set-up may disturb the field management. For this reason, no photoeclector traps can be placed on asparagus fields to determine the emergence rate of asparagus flies directly. Therefore, the objectives of conducting soil sampling and artificial trials in this study were: (i) to evaluate the efficacy of on-farm mechanical foliage processing and soil tillage systems as a measure against asparagus fly and, in this context, (ii) to elucidate the influence of soil depth, e.g. mechanical burying of pupae, on the emergence rate of asparagus fly pupae.

\section{Materials and Methods}

\section{Evaluation of On-farm Soil Tillage Systems}

Asparagus fields were sampled during $2017(n=2)$ and $2018(n=4)$ for soil containing asparagus fly pupae in the regions of Hannover and Braunschweig in Lower Saxony, Germany. Only fields with asparagus fly activity, proven using green stick Bio-Colortraps ${ }^{\circledR}$ (Temmen GmbH, Hattersheim), were chosen. The most well-suited and comparable places for soil sampling were determined by previous 
Fig. 1 a asparagus stems after mulching; b sampling of asparagus stems before the mechanical processing for the controls; c boxes with soil samples in the greenhouse, $\mathbf{d}$ setup of the pupae-soil depth trial in 2017
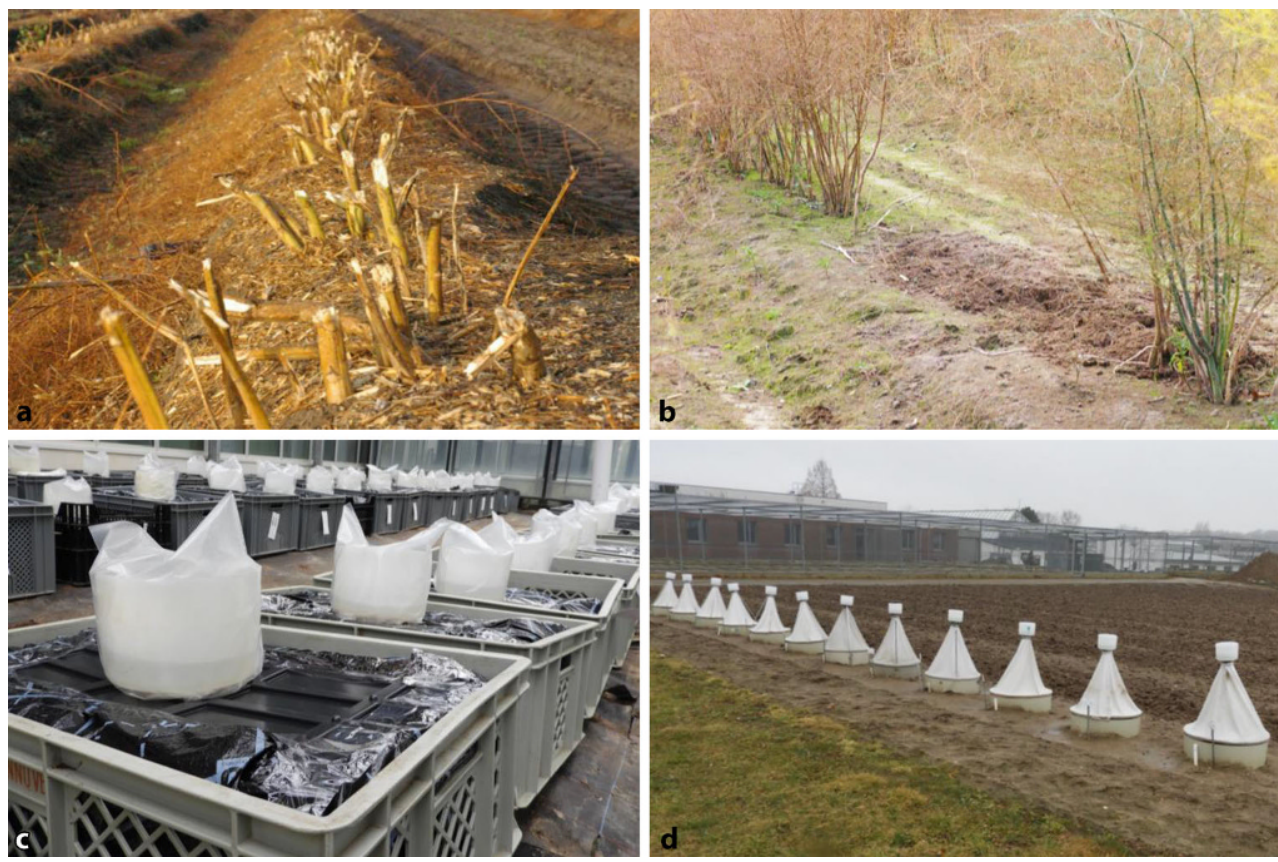

checks of infestation intensity at 45 spots evenly distributed across the field.

In line with common practice in all the fields, white asparagus was produced by forming $50-\mathrm{cm}$ high dams while green asparagus was grown without a dam in Watenbüttel. After harvest, the dams on the white asparagus fields were not levelled. Mechanical processing of the fern was routinely performed in the months of October and November (Fig. 1a). On the Fuhrberg 2 field, however, the first rotary step was performed in December 2018 and the second in February 2019. The fields differed in terms of the agricultural equipment used (Table 1) and the combination of mechanical processing steps (Table 2). In each field, four samples were taken from pre-assigned sites
Table 1 Devices used for the mechanical distortion of asparagus fern and soil tillage in the asparagus fields sampled in 2017 and 2018

Table 2 Soil sampling of asparagus fields in the Hannover and Braunschweig regions in the autumn of 2017 and 2018 for pupae of asparagus fly (Plioreocepta poeciloptera). The samples were taken before (control) and after the described mechanical processing steps with front $(\mathrm{F})$ and rear $(\mathrm{R})$ tractormounted implements indicated

\begin{tabular}{|c|c|c|c|c|}
\hline Field location & Implement & Company, location & Model & Type \\
\hline \multirow[t]{3}{*}{ Fuhrberg 1} & Mulcher & \multirow{3}{*}{$\begin{array}{l}\text { Acker S. A. } \\
\text { Konstantinidis, } \\
\text { Thessaloniki, Greek }\end{array}$} & KTSFNS & 175 \\
\hline & Rotary tiller & & SKFH & 105 \\
\hline & Dam former & & SPRGR & 230 \\
\hline Hassel & Mulcher & $\begin{array}{l}\text { Müthing GmbH \& Co. KG } \\
\text { Soest, Germany }\end{array}$ & $\begin{array}{l}\text { MU-M } \\
\text { Vario }\end{array}$ & 280 \\
\hline \multirow[t]{2}{*}{ Watenbüttel } & Mulcher & $\begin{array}{l}\text { Metasa GmbH, Gladbeck, } \\
\text { Germany }\end{array}$ & Mulcher & 1420 \\
\hline & Rotary tiller & $\begin{array}{l}\text { Howard Rotavator GmbH, } \\
\text { Michelstadt, Germany }\end{array}$ & HR 20 & $155 \mathrm{SU}$ \\
\hline \multirow[t]{2}{*}{ Fuhrberg 2} & Mulcher & $\begin{array}{l}\text { Acker S. A. Konstantini- } \\
\text { dis, Thessaloniki, Greek }\end{array}$ & KTSFNS & 175 \\
\hline & $\begin{array}{l}\text { Rotary tiller supplemented } \\
\text { with two disc ploughs }\end{array}$ & $\begin{array}{l}\text { Howard Rotavator GmbH, } \\
\text { Michelstadt, Germany }\end{array}$ & HR 20 & - \\
\hline
\end{tabular}

\begin{tabular}{lllll}
\hline Year & Field location & \multicolumn{2}{l}{ Processing steps prior to sampling with device (F/R) } \\
\cline { 3 - 5 } & & 1 & 2 & 3 \\
\hline 2017 & Fuhrberg 1 & Mulcher/- & $\begin{array}{l}\text { Rotary tiller/dam } \\
\text { former }\end{array}$ & - \\
2018 & Hassel & Mulcher/- & - & - \\
& Watenbüttel & Mulcher/rotary tiller & - & - \\
2018 & Fuhrberg 2 & Mulcher/- & Rotary tiller/- & Rotary tiller/- \\
\hline
\end{tabular}


randomly distributed across the field. A sample consisted of a mixture of soil and shredded plant material taken from a $2 \mathrm{~m} \times 1 \mathrm{~m} \times 0.3 \mathrm{~m}$ (length $\times$ width $\times$ depth) dam section with a total volume of $100 \mathrm{~L}$. Samples were taken after the first, second or third processing step depending on the location, irrespective of how many subsequent steps there were. Control samples were taken before the first processing step and consisted of all asparagus stems within the $2 \mathrm{~m}$ dam section (Fig. 1b), cut $5 \mathrm{~cm}$ beneath the soil surface. The control and sampling sites were in close proximity.

Further processing of the samples comprised a subdivision into three subsamples, each of which was placed on black micro-perforated film laid out in plastic boxes (Bekuplast, Ringe, Germany) $400 \mathrm{~mm} \times 600 \mathrm{~mm} \times 274 \mathrm{~mm}$ (length $\times$ width $\times$ height). The boxes were covered with the film and equipped with a photoeclector trap (ecoTech, Bonn, Germany) to prevent emerging flies from escaping and ensure they were trapped in the eclector vessel. Boxes were placed in a greenhouse without additional climate control to stay as close to natural conditions as possible (Fig. 1c). At the start of the following April, the number of emerged asparagus flies were counted twice a week. The cumulative counts served as a measurement of survival success for the different types of mechanical processing.

In 2018 an additional field in Fuhrberg (Table 2) was investigated on which two subsequent working steps with a rotary tiller were performed. At this location, the additional effect of the second tillage was examined by making a comparison between the two tillage steps only.

To address any possible lethal effects of sample processing, water flotation extraction was used with subsamples of $5 \mathrm{~L}$ per box to check the number of unhatched dead pupae in August after the hibernation period in 2018.

\section{Trials on Emergence Rate Depending on Pupae Soil Depth}

Pupae found during the monitoring assessments in autumn were kept on quartz sand with added vermiculite in aerated plastic vessels (Runddose V2-80, Licefa GmbH \& Co KG, Germany). The vessels were placed without an additional cover in a roof-covered outdoor insectary exposed to natural temperature conditions, but protected from precipitation. Trials started in December and were conducted until the spring of 2018 and 2019 in Braunschweig, Germany.

In 2017, the trial was set up as a block design with four replicates (Fig. 1d). Each replicate consisted of four holes either $10 \mathrm{~cm}$ or $20 \mathrm{~cm}$ deep drilled with a soil sampler $(\varnothing$ $2 \mathrm{~cm}$ ). Each hole received 12 pupae, resulting in 48 pupae per replicate and a total number of 192 per soil depth. The holes were filled with soil again afterwards. The pupae originated from different fields during the infestation controls in the autumn and were thoroughly mixed prior to their use in the trials. All remaining pupae from the chosen fields remained separated by field in the insectary and were used for control purposes.

In 2018, the trial was set up with five replicates and 36 pupae each ( $n=180$ for each variant). Twelve holes were made and each hole received only three pupae to reduce the risk of losing several pupae by single infestations with pathogens.

To catch the emerged flies, photoeclector traps (ecoTech, Bonn, Germany) covering $0.25 \mathrm{~m}^{2}$ of the soil surface were placed over the holes. The replicates were in a row, therefore the photoeclector traps were $30 \mathrm{~cm}$ apart. The eclectors remained open until January when the risk of damage due to frozen trap fluid was low. They were then fitted with trap vessels. Photoeclector traps were checked for emerged flies twice a week from March to July. The assessment ended when hatching was no longer observed for two successive weeks. The ratio of emerged flies to total flies per replicate was used for further analysis.

\section{Statistical Analyses}

Data for mechanical processing were analysed using generalised linear mixed-effects models (GLMM) with negative binomial distribution with the lme4 package (Bates et al. 2015). The counts of emerged flies were tested for their relationship with the interaction of the year of trial and the method of mechanical processing, i.e. mulching alone or mulching with subsequent tillage. The control samples taken prior to mechanical processing were treated as a separate method in the soil processing analysis. Field location was used as a random factor to account for variability when repeatedly taking samples from the same field, i.e. control and treatment samples. To account for differences between groups, $95 \%$ confidence intervals were calculated. These are shown in brackets after the estimated fly numbers from the models.

Data on the relative numbers of emerged flies from the soil depth investigations were analysed using general linear models (GLMs) assuming binomial distribution. The explanatory variables were year of investigation and soil depth. The latter included one level for observations under natural temperature conditions from the outside insectary.

$P$ values for the significance of explanatory variables were determined by means of likelihood ratio tests (LRT) in the GLMs. For GLMMs, the marginal $\mathrm{R}^{2}$ value and dispersion parameter were preferred over $p$ values to judge goodness of fit. The best models were chosen based on the Akaike information criterion (AIC). Post hoc multicomparisons were performed using estimated marginal means with the emmeans package (Lenth 2020). For data analysis, GNU R (R Core Team 2020) was used. 


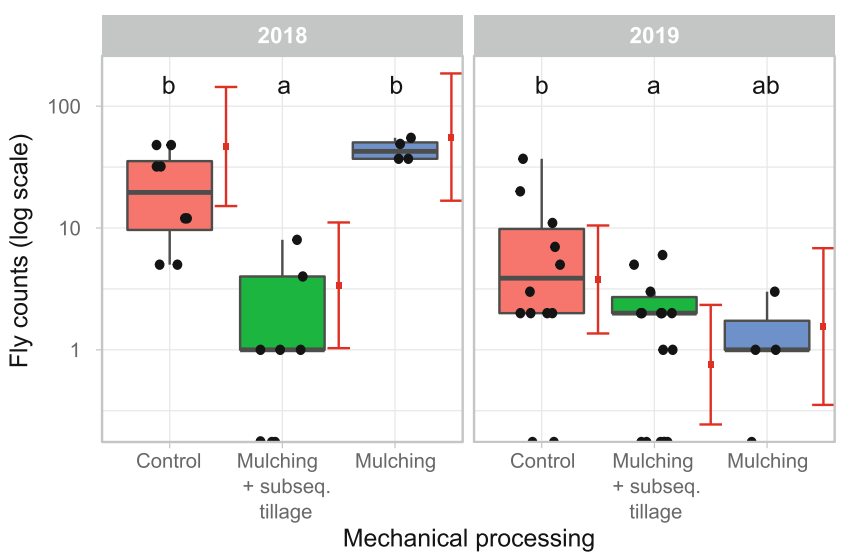

Fig. 2 Emerged asparagus flies in 2018 and 2019 from soil samples taken on asparagus fields after mulching of the asparagus fern alone or subsequent tillage by rotary tillers or rotary tillers with dam formation the previous autumn. Control samples were taken from the same field before mechanical processing was performed. The counts are presented in boxplots on a log scale. Black dots: emerged flies in one sample. Red squares: model estimates from negative binomial GLMM with 95\% confidence intervals. Letters indicate significant differences for treatments for the year of investigation

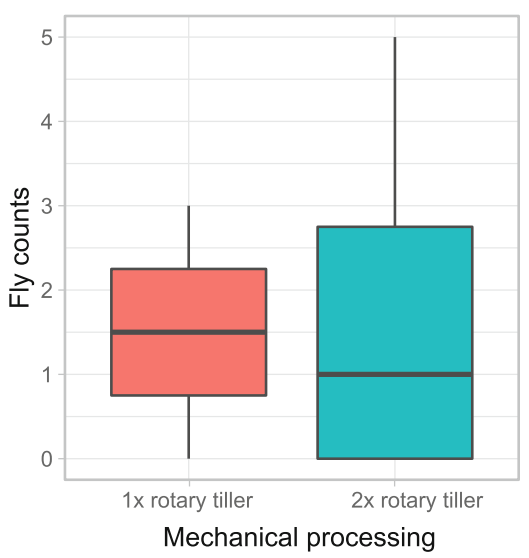

Fig. 3 Comparison of emerged asparagus flies from soil samples taken from an asparagus field in 2018 after mulching and one rotary tiller step, and after a subsequent second rotary tiller step the previous autumn. The counts are presented in boxplots ( $\mathrm{t}-$ Test: $\mathrm{t}=-0.29 ; \mathrm{df}=3$, $p=0.8)$

\section{Results}

\section{Mechanical Processing}

The best-fitting model included an interaction term of processing method and year (GLMM, $\mathrm{R}_{\text {marginal: }}^{2} 0.62$, dispersion parameter: 1.09 , family: negative binomial). In both years, there was a significant decrease in the numbers of flies when the procedure included a subsequent tillage step after mulching of asparagus fern. In 2018, the estimated number of flies per $2 \mathrm{~m}$ dam length was $3.4[1.0,11.1]$ after mulching and rotary tillage compared with $55.8[16.8$, 185.7] after mulching alone and $46.6[15.13,143.81]$ in

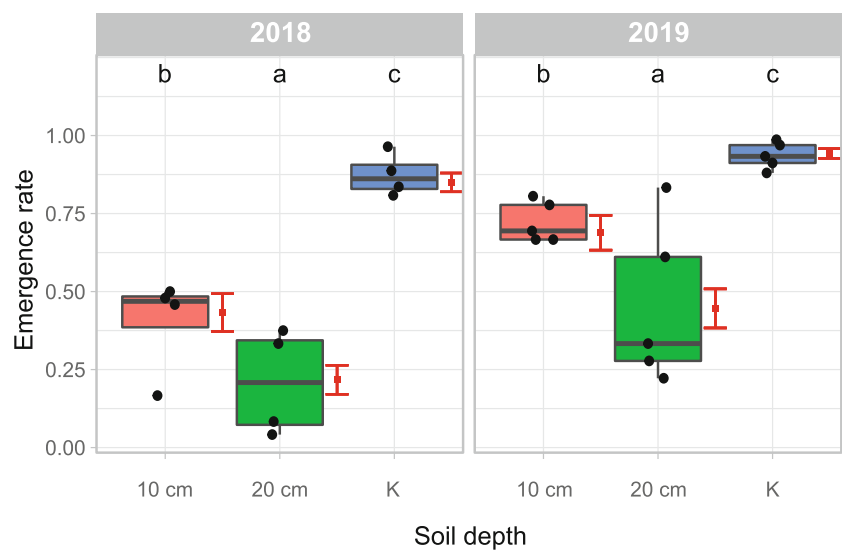

Fig. 4 Emergence rates of asparagus flies in the spring of 2018 and 2019 with pupae buried at different soil depths the previous autumn and control sets from the insectary. Boxplots with model predictions. Black dots: emerged flies in relation to buried pupae ( $N=48$ in 2018; $N=36$ in 2019). Red squares: model estimates from binomial GLM with a $95 \%$ confidence interval. Letters indicate significant differences for treatment type

the control samples. In 2019, fly emergence was lower overall, and the number of flies after combined mulching and tillage was $0.75[0.2,2.3]$ compared with $1.6[0.35$, 6.8] after mulching and $3.8[1.4,10.5]$ in the control samples (Fig. 2). Therefore, it was apparent that application of mulching alone delivered more variable results than the use of tillage after mulching. The number of emerged flies was not significantly reduced by mulching alone in either year. The results of the separate analysis of the tillage trial in 2018 indicated that the emergence rate could not be further reduced by additional tilling steps (Fig. 3). In 2018 no vital pupae, only empty ones, were found in the washed soil subsamples, indicating that all the flies had hatched as expected with this method and no confounding effects of method biased the results.

\section{Pupae Depth}

GLMs for emergence rate showed significant main effects for year (LRT, $p<0.001)$ and soil depth (LRT, $p<0.001$ ). The interaction of the two factors had no significant influence on the emergence rate. Therefore, the results showed that the differences in the two trials were significant, while the treatment effects were consistent and unaffected by differences in methods or environmental conditions. The emergence rate for the insectary control was consistently high at $0.84[0.81,0.87]$ in spring 2018 and $0.94[0.92,0.95]$ in spring 2019.

Although the rate of emerging flies from $20 \mathrm{~cm}$ and $10 \mathrm{~cm}$ soil depth was more variable between the years than between the treatments, in both years, however, hatch rates from $20 \mathrm{~cm}$ depth were significantly lower than from $10 \mathrm{~cm}$ depth and the controls from the insectary (Fig. 4). The rate 
of emerging flies was $0.22[0.17,0.26]$ in 2018 and 0.45 $[0.38,0.50]$ in 2019 . The emergence rate for pupae buried at $20 \mathrm{~cm}$ depth was 0.50 less than the insectary control and 0.23 less than the $10 \mathrm{~cm}$ treatment in 2019 , and for 2018 the difference was 0.62 less than the control and 0.21 less than the $10 \mathrm{~cm}$ treatment. The highest average emergence rates observed were $0.45[0.38,0.50]$ for the $20 \mathrm{~cm}$ treatment and $0.68[0.63,0.74]$ for the $10 \mathrm{~cm}$ treatment.

\section{Discussion}

Mulching by cutting and shredding asparagus fern, followed by tillage with rotary tillers and subsequent dam formation, is a common practice in German asparagus cultivation. However, the implements used vary depending on the growing region, cultivation method and farmers' preferences. This study showed that the number of flies emerging from soil samples the following spring was not significantly reduced by mulching alone. This is because the pupae, which are lying in the asparagus stems just beneath the soil surface (Otto 2002), might not be affected solely by aboveground processing of the asparagus fern.

However, the number of emerged flies from soil samples taken after either rotary tilling or rotary tilling and dam formation was significantly reduced. Control samples obtained via floatation extraction showed no dead or mechanically damaged pupae, indicating that all the pupae that were in the soil sample had hatched. Therefore, the reduced number of emerged flies is best explained by an already reduced number of pupae in the soil samples taken from these treatments. Owing to the limited amount of data, the effect of rotary tillers and dam-forming steps could not be statistically assessed separately in this study. But given that inversion of the soil by rotary tillers is low or does not occur at all (Mohler et al. 2006), in contrast to the high vertical movement of the soil by ploughing (Scanlan and Davies 2019), it can be hypothesised that the reduction of pupae in the soil samples is solely a consequence of dam formation. This is a reasonable hypothesis given that the soil used to make the dams comes from between the dams and thus does not contain asparagus stems or asparagus fly pupae.

The effects of different soil cultivation methods on insects may vary between species, time of cultivation, soil type and insect life stage (Johnson et al. 1984; Stinner and House 1990; Seal et al. 1992; Chu et al. 1996; Holland and Luff 2000; Holland and Reynolds 2003; Baughman et al. 2015; Matlock et al. 2017; Alyokhin et al. 2020) and cannot be generalised. Since the soil samples were mixed before the boxes were filled, the depth position of the individual pupae within the boxes can be expected to be random. Therefore, the influence of depth on the emergence of adult flies could not be compared between the treatments for this part of the study. However, further investigations showed that under natural conditions, the number of emerging asparagus flies decreased significantly with increasing pupae soil depth. Two negative effects could play an essential role here: the reduction of the pupae hatching rate by direct exposure to adverse environmental conditions and/or the reduction in the number of adult flies successfully reaching the soil surface. Examples of the role played by both effects can be found in different studies. According to investigations by Finch and Skinner (1980) on the cabbage root fly Delia radicum, the depth of the pupae has no influence on the percentage of adults emerging from the pupae, but rather on the number of the adults that fail to reach the soil surface. In contrast, the hatching rates of pupae can be reduced by a high soil moisture content, which has been shown for Oriental fruit fly (Bactrocera dorsalis) and Western cherry fruit fly (Rhagoletis indifferens) (Hou et al. 2006; Yee 2013) or additional unfavourable temperatures, which is the case for the pupae of the Mediterranean fruit fly Ceratitis capitata (Quesada-Moraga et al. 2012). The time spent in the waterlogged substrate, the pupation substrate itself, and the sex of the pupae may also play essential roles in the proportion of imagines emerging from pupae, as observed by Leather (1984) for the moth Panolis flammea.

On the assumption that piling soil onto pupae has the same effect as digging pupae into the soil, it could be concluded that dam formation might be the crucial tillage measure in asparagus production in view of the reduction of the number of emerging asparagus flies the following year. However, elucidation of the mechanisms of tillage measures on asparagus fly pupae was not within the scope of this study and requires further investigation.

\section{Conclusion}

This study demonstrated that the asparagus fly population can be reduced effectively by routine on-farm tillage methods. While tillage might have a negative impact on non-target invertebrates (Rowen et al. 2020), this effect should be offset against the overall decrease in the asparagus fly population and thus against the benefits of a reduction in insecticidal treatments. Routine on-farm tillage methods should therefore be considered an effective physical measure that contributes to integrated pest management (IPM) in asparagus production.

Acknowledgements The authors would like to thank Imke Stark for her dedicated technical assistance. We are also grateful to Jörg Heuer, Uwe Möhring, Olaf Pape, Andreas Schröder, Hans-Henrich Wendt and Dr. Moritz Wendt for their practical support and valuable discussions during the project. The project was supported by funding from the Federal Ministry of Food and Agriculture (BMEL) based on a decision of 
the Parliament of the Federal Republic of Germany via the Federal Office for Agriculture and Food (BLE) under the Federal Programme for Ecological Farming and Other Forms of Sustainable Agriculture.

Funding Open Access funding enabled and organized by Projekt DEAL.

Conflict of interest A. Wichura, Q. Schorpp, V. Kühlmann and M. Hommes declare that they have no competing interests.

Open Access This article is licensed under a Creative Commons Attribution 4.0 International License, which permits use, sharing, adaptation, distribution and reproduction in any medium or format, as long as you give appropriate credit to the original author(s) and the source, provide a link to the Creative Commons licence, and indicate if changes were made. The images or other third party material in this article are included in the article's Creative Commons licence, unless indicated otherwise in a credit line to the material. If material is not included in the article's Creative Commons licence and your intended use is not permitted by statutory regulation or exceeds the permitted use, you will need to obtain permission directly from the copyright holder. To view a copy of this licence, visit http://creativecommons.org/licenses/by/4. $0 /$.

\section{References}

Alyokhin A, Nault B, Brown B (2020) Soil conservation practices for insect pest management in highly disturbed agroecosystems-a review. Entomol Exp Appl 168(1):7-27. https://doi.org/ 10.1111/eea.12863

Bates D, Mächler M, Bolker B, Walker S (2015) Fitting linear mixedeffects models using lme4. J Stat Soft 67(1):48. https://doi.org/10. 18637/jss.v067.i01

Baughman WB, Nelson PN, Grieshop MJ (2015) Impact of cultivation and subsequent burial on Cydia pomonella (lepidoptera: Tortricidae) and Conotrachelus nenuphar (Coleoptera: Curculionidae). J Econ Entomol 108(3):1215-1220. https://doi.org/10.1093/jee/ tov071

Chu CC, Henneberry TJ, Weddle RC, Natwick ET, Carson JR, Valenzuela C, Birdsall SL, Staten RT (1996) Reduction of pink bollworm (Lepidoptera: Gelechiidae) populations in the Imperial Valley, California, following mandatory short-season cotton management systems. J Econ Entomol 89(1):175-182. https://doi.org/10. 1093/jee/89.1.175

Crüger G, Backhaus GF, Hommes M, Smolka S, Vetten H-J (2002) Pflanzenschutz im Gemüsebau, 4th edn. Ulmer,

Dingler M (1934a) Die Spargelfliege (Platyparea poeciloptera Schrank) I. Teil. Arb Physiol Angew Entomol Berlin-Dahlem 1:131-162

Dingler M (1934b) Die Spargelfliege (Platyparea poeciloptera Schrank) II. Teil. Arb Physiol Angew Entomol Berlin-Dahlem 1:185-217

Drake CJ, Harris HM (1932) Asparagus insects in Iowa. Circular. Paper 134. https://lib.dr.iastate.edu/iaes_circulars/147

Finch S, Skinner G (1980) Mortality of overwintering pupae of the cabbage root fly (Delia brassicae). J Appl Ecol 17(3):657-665. https://doi.org/10.2307/2402644

Fischer S, Freuler J, Mittaz C, Terrettaz C (1989) La mouche de l'asperge Platyparea poeciloptera Schrank (Diptera, Tephritidae) en Valais (The asparagus fly Platyparea poeciloptera Schrank (Diptera, Tephritidae) in Valais). Rev Suisse Vitic Arboric Hortic 21(5):295-306

Giard A (1903) La mouche de l'asperge (Platyparea poeciloptera Schrank) et ses ravages à Argenteuil. C R Seances Soc Biol Fil 55(24):907-910

Holland JM, Luff ML (2000) The effects of agricultural practices on Carabidae in temperate agroecosystems. Integr Pest Manag Rev 5(2):109-129. https://doi.org/10.1023/A:1009619309424
Holland JM, Reynolds CJM (2003) The impact of soil cultivation on arthropod (Coleoptera and Araneae) emergence on arable land. Pedobiologia 47(2):181-191. https://doi.org/10.1078/0031-405600181

Hou B, Xie Q, Zhang R (2006) Depth of pupation and survival of the Oriental fruit fly, Bactrocera dorsalis (Diptera: Tephritidae) pupae at selected soil moistures. Appl Entomol Zool 41(3):515-520. https://doi.org/10.1303/aez.2006.515

Johnson TB, Turpin FT, Schreiber MM, Griffith DR (1984) Effects of crop-rotation, tillage and weed management-systems on Black Cutworm (Lepidoptera, Noctuidae) infestations in corn. J Econ Entomol 77(4):919-921. https://doi.org/10.1093/jee/77.4.919

Krüger F (1905) Der Spargelrost und die Spargelfliege und ihre Bekämpfung. Flugblatt, vol Nr. 12. Kaiserliche Biologische Anstalt für Land- und Forstwirtschaft,

Leather SR (1984) Factors affecting pupal survival and eclosion in the pine beauty moth, Panolis flammea (D \& S). Oecologia 63(1):75-79

Lenth R (2020) emmeans: estimated marginal means, aka least-squares means. In: Bd R package version 1.4.5

Matlock JM, Isaacs R, Grieshop M (2017) Tillage reduces survival of grape berry moth (Lepidoptera: Tortricidae), via burial rather than mechanical injury. Environ Entomol 46(1):100-106. https://doi. org/10.1093/ee/nvw149

Mohler CL, Frisch JC, McCulloch CE (2006) Vertical movement of weed seed surrogates by tillage implements and natural processes. Soil Tillage Res 86(1):110-122. https://doi.org/10.1016/j. still.2005.02.030

Niblett M (1956) The flies of the London area. Ill. Trypetidae. Lond Nat 1955:82-88

Otto M (2002) Populationsökologische Untersuchungen zur Spargelfliege (Platyparea poeciloptera) und Zwiebelfliege (Delia antiqua) unter besonderer Berücksichtigung des Einsatzes von Simulationsmodellen im Integrierten Pflanzenschutz. University Bayreuth, Bayreuth (Dissertation)

Quesada-Moraga E, Valverde-García P, Garrido-Jurado I (2012) The effect of temperature and soil moisture on the development of the preimaginal mediterranean fruit fly (Diptera: Tephritidae). Environ Entomol 41(4):966-970. https://doi.org/10.1603/en12029

R Core Team (2020) R: a language and environment for statistical computing. Computing RFfS, Vienna

Rowen EK, Regan KH, Barbercheck ME, Tooker JF (2020) Is tillage beneficial or detrimental for insect and slug management? A meta-analysis. Agric Ecosyst Environ. https://doi.org/10.1016/j. agee.2020.106849

van Rozen K, Ester A (2006) Bestrijding aspergevlieg en aspergekever : veldonderzoek naar middelen om de aspergevlieg Platyparea poeciloptera en de aspergekever Crioceris spp. te bestrijden in de aspergeteelt 2006. Praktijkonderzoek Plant \& Omgeving, PPOagv, Lelystad

Scanlan CA, Davies SL (2019) Soil mixing and redistribution by strategic deep tillage in a sandy soil. Soil Tillage Res 185:139-145. https://doi.org/10.1016/j.still.2018.09.008

Seal DR, Chalfant RB, Hall MR (1992) Effects of cultural-practices and rotational crops on abundnance of wireworms (Coleoptera: Elateridae) affecting sweet-potato in Georgia. Environ Entomol 21(5):969-974. https://doi.org/10.1093/ee/21.5.969

Stinner BR, House GJ (1990) Arthropods and other invertebrates in conservation-tillage agriculture. Annu Rev Entomol 35(1): 299-318. https://doi.org/10.1146/annurev.en.35.010190.001503

Yee WL (2013) Soil moisture and relative humidity effects during postdiapause on the emergence of western cherry fruit fly (Diptera: Tephritidae). Can Entomol 145(3):317-326. https://doi.org/10. 4039/tce.2013.7 
Alexandra Wichura achieved her doctoral grade in phytopathology at the University of Hannover. Since 2007, she has been responsible for the plant protection in vegetables and fruit at the Plant Protection Service, Lower Saxony. 